\title{
Female Sex Trafficking: Conceptual Issues, Current Debates, and Future Directions
}

Citation for published version (APA):

Meshkovska, B., Siegel, M., Stutterheim, S. E., \& Bos, A. E. R. (2015). Female Sex Trafficking:

Conceptual Issues, Current Debates, and Future Directions. Journal of Sex Research, 52(4), 380-395. https://doi.org/10.1080/00224499.2014.1002126

Document status and date:

Published: 01/01/2015

DOI:

10.1080/00224499.2014.1002126

Document Version:

Publisher's PDF, also known as Version of record

Document license:

Taverne

\section{Please check the document version of this publication:}

- A submitted manuscript is the version of the article upon submission and before peer-review. There can be important differences between the submitted version and the official published version of record.

People interested in the research are advised to contact the author for the final version of the publication, or visit the DOI to the publisher's website.

- The final author version and the galley proof are versions of the publication after peer review.

- The final published version features the final layout of the paper including the volume, issue and page numbers.

Link to publication

\footnotetext{
General rights rights.

- You may freely distribute the URL identifying the publication in the public portal. please follow below link for the End User Agreement:

www.umlib.nl/taverne-license

Take down policy

If you believe that this document breaches copyright please contact us at:

repository@maastrichtuniversity.nl

providing details and we will investigate your claim.
}

Copyright and moral rights for the publications made accessible in the public portal are retained by the authors and/or other copyright owners and it is a condition of accessing publications that users recognise and abide by the legal requirements associated with these

- Users may download and print one copy of any publication from the public portal for the purpose of private study or research.

- You may not further distribute the material or use it for any profit-making activity or commercial gain

If the publication is distributed under the terms of Article $25 \mathrm{fa}$ of the Dutch Copyright Act, indicated by the "Taverne" license above, 
Journal of Sex Research

\title{
Female Sex Trafficking: Conceptual Issues, Current Debates, and Future Directions
}

\author{
Biljana Meshkovska, Melissa Siegel, Sarah E. Stutterheim \& Arjan E. R. Bos
}

To cite this article: Biljana Meshkovska, Melissa Siegel, Sarah E. Stutterheim \& Arjan E. R. Bos (2015) Female Sex Trafficking: Conceptual Issues, Current Debates, and Future Directions, Journal of Sex Research, 52:4, 380-395, DOI: 10.1080/00224499.2014.1002126

To link to this article: https://doi.org/10.1080/00224499.2014.1002126

\section{曲 Published online: 21 Apr 2015.}

Submit your article to this journal ¿t

\section{Џll Article views: 3355}

Q View related articles $\square$

View Crossmark data ¿

4

Citing articles: 9 View citing articles $\sqsubset$ 


\title{
ANNUAL REVIEW OF SEX RESEARCH SPECIAL ISSUE
}

\section{Female Sex Trafficking: Conceptual Issues, Current Debates, and Future Directions}

\author{
Biljana Meshkovska and Melissa Siegel \\ Maastricht Graduate School of Governance, Maastricht University \\ Sarah E. Stutterheim and Arjan E. R. Bos \\ Faculty of Psychology and Educational Sciences, Open University of the Netherlands
}

\begin{abstract}
Female sex trafficking is a pressing concern. In this article, we provide a comprehensive overview of relevant issues regarding the concept of female sex trafficking and research in the field of human trafficking, drawing on a variety of disciplines, including economics, gender and sexuality studies, psychology, sociology, law, and social work. We discuss the debates surrounding the definition of human trafficking, compare and contrast it with human smuggling, and outline connections between female sex trafficking and the issue of sex work and prostitution. We further discuss the history and current estimations of female sex trafficking. We then outline the main actors in female sex trafficking, including trafficked persons, traffickers, clients, and service providers, and we overview the trafficking process from recruitment to identification, recovery, and (re)integration. Finally, we conclude with recommendations for future research that tie together the concepts of vulnerability, exploitation, and long-term recovery and (re)integration.
\end{abstract}

Human trafficking is a pressing concern with substantive negative consequences for its victims. It carries relevance for a variety of actors, from the individual looking for employment, or looking to migrate, to the international community responsible for the safety of those targeted. This interest in human trafficking has produced a plethora of information, much of which is not based on rigorous empirical research. Much of the information available is the product of heated debates on issues pertaining to security, human smuggling, female migration, and prostitution. To a lesser extent, information is yielded from lessons learned in the field. Last, and unfortunately, a small portion of the literature is simply a consequence of speculation and marked by inaccuracy. Within the literature on human trafficking the focus has primarily been placed on female sex trafficking because it is one of the most severe forms of human trafficking, and thus it is this type of trafficking that most researchers attempt to analyze and understand. A thorough review of the available

Correspondence should be addressed to Biljana Meshkovska, Maastricht Graduate School of Governance, Maastricht University, P.O. Box 616, 6200 MD, Maastricht, The Netherlands. E-mail: b.meshkovska@maastrichtuniversity.nl literature on female sex trafficking that seeks to identify the most urgent issues of concern and to disentangle reality from myth is crucial, because the existing literature informs policies that aim to tackle human trafficking and assist those who have been affected by it. The purpose of this article is therefore to provide a comprehensive overview of the main themes involved in female sex trafficking and to identify the gaps to be filled.

We start this review by defining human trafficking and then briefly discuss current issues of contention in human trafficking, such as the overlap between trafficking and smuggling and the link between female sex trafficking and sex work. As current issues have their roots in the past, we also include a short historical review that touches on White slavery and the historical origins of sex trafficking. Following that, we review different approaches to sex trafficking, including trafficking as a security issue, trafficking as a migration issue, and trafficking as a human rights issue. Thereafter, we provide an overview of the main actors that play a role in sex trafficking processes, namely trafficked women, traffickers, clients, and the central service provider for persons trafficked. After the overview of the main actors, the focus shifts to the trafficking process, including methods of recruitment and characteristics of the 
trafficking process. We then discuss methods of identification and follow the processes of recovery and reintegration of trafficked persons before discussing directions for future research.

\section{Method}

The main themes of this article were determined and outlined as a result of a preliminary review of literature on human trafficking in general and sex trafficking in particular. Thereafter, a thorough review of Englishlanguage literature was conducted to identify the most relevant studies within each theme. Google Scholar, PsychINFO, Web of Science, ProQuest, Scopus, and Medline were the main databases used. The primary keyword employed was human trafficking. This term yielded 35,300 hits in Google Scholar, 2,668 hits in ProQuest, 16,651 hits in Web of Science, 359 in Scopus, and 143 hits in Medline. Each set of hits was subsequently sorted by relevance. The same methodology was employed for the following additional keywords: protocol, definition, sexual exploitation, sex trafficking, smuggling, prostitution, sex work, history, security, migration, human rights, trafficked person, actor, victim, survivor, trafficker, demand, customer, client, service provider, recruitment, trafficking experience, identification, recovery, integration, and reintegration. Based on the relevance of the title and the contents of the abstract to the identified themes, a final selection of 241 items, including 206 articles, 21 books, and 14 reports, was made, all of which were read in detail. Of those 241, 138 (113 articles, 7 books, 14 reports, 2 official documents, 1 discussion paper, 1 handbook) were selected for inclusion in the review. Literature was chosen for inclusion based on the relevance to the topic covering the major themes identified as important points of discussion for this article. Papers covering conceptual issues were selected on the basis of how current and relevant the topic addressed was to ongoing debates in the field, how critical and well argued the approach, and the clarity of writing. Empirical papers were chosen on the basis of a sound and transparent methodology as well as quality analyses. The final group of selected literature also includes gray literature, such as reports commissioned or published by international government organizations or research institutes. Gray literature was included when the contents were deemed important for understanding a current trend in the field, such as when discussing the scope and geographical distribution of female sex trafficking as well as practices of recovery and reintegration. Finally, relevant treaties, reports, and documents from the United Nations, United Nations Office on Drugs and Crime (UNODC), UN.GIFT, European Union (EU), International Organization of Migration (IOM), International Labor Organization (ILO). and the U.S. State Department were included. It is important to note that the issue of human trafficking has been shaped through internationally debated and UN-initiated documents. Thus, this review pays attention to these documents, particularly as they pertain to definitions of human trafficking and sex trafficking. The selected literature covers January 1, 1999, to April 30, 2014. We opted not to search for literature that was published prior to January 1, 1999, because the definition of human trafficking as it is today was introduced in 2000.

\section{A Definition of Human Trafficking}

The contemporary and commonly accepted definition of human trafficking was introduced in 2000 by the United Nations Protocol to Prevent, Suppress, and Punish Trafficking in Persons, Especially Women and Children. According to this United Nations protocol, human trafficking is

\begin{abstract}
the recruitment, transportation, transfer, harboring or receipt of persons, by means of threat or use of force or other forms of coercion, of abduction, of fraud, of deception, of the abuse of power or of a position of vulnerability or of the giving or receiving of payments or benefits to achieve the consent of a person having control over another person, for the purpose of exploitation. Exploitation includes, at a minimum, the exploitation of the prostitution of others or other forms of sexual exploitation, forced labour or services, slavery or practices similar to slavery, servitude or the removal of organs. (UNODC, 2003b, p. 2)
\end{abstract}

The protocol continues with Article 3 (b), which states that consent is irrelevant, should any of the means noted be used. Finally, Article 3 concludes by noting that means are irrelevant when the person is a child, or under age 18 .

Based on the UN definition, Gallagher (2010) distinguished three elements that must be present for trafficking to have occurred: "(1) ACTION: recruitment, transportation, transfer, harboring or receipt of persons; (2) MEANS: threat or use of force or other forms of coercion, of abduction, of fraud, of deception, of the abuse of power or of a position of vulnerability or of the giving or receiving of payments or benefits to achieve the consent of a person having control over another person; and (3) PURPOSE: exploitation" (p. 29).

It should be noted that the UN protocol speaks not only of women and girls, but also of men and children (UNODC, 2013). In addition, the inclusion of the segment "harbouring or receipt of persons" makes clear that human trafficking is not just a process; it also pertains to the maintenance of a situation of "exploitation" (Gallagher, 2010; UNODC, 2013). Finally, the protocol also indicates that trafficking occurs not only across but also within borders (UNODC, 2013).

Despite its comprehensive nature, the UN protocol leaves numerous questions unanswered and from its inception these have given rise to debate. One issue of 
contention is the interchangeability between trafficking and smuggling in practice. Another is the issue of "consent" in the context of sex trafficking.

\section{Current Debates: Human Trafficking versus Human Smuggling}

Shortly after introducing the Anti-Trafficking Protocol, the UN also introduced a protocol against the smuggling of migrants by land, sea, and air as a supplement to the United Nations Convention Against Transnational Organized Crime. In this protocol, the smuggling of migrants was defined as "the procurement, in order to obtain, directly or indirectly, a financial or other material benefit, of the illegal entry of a person into a State Party of which the person is not a national or a permanent resident" (UNODC, 2003a, p. 2).

As the purpose of this protocol is to "prevent and combat the smuggling of migrants" (UNODC, 2003a), we can contend that smuggling differs from trafficking in that smuggling requires the crossing of borders. In contrast, trafficking can happen within the confines of state borders. In addition, smuggled migrants, unlike trafficked persons, can be deported to their country of origin immediately on identification, without the possibility of being offered temporary or permanent residence, as is the case for some trafficked persons in certain countries and situations (Gallagher, 2010).

Although these distinctions may be clear on paper, in practice it is difficult to distinguish trafficking from smuggling, particularly when one takes into consideration differences in definitions of smuggling introduced at national levels (Aronowitz, 2001; O'Connell Davidson, 2013). According to Aronowitz (2001), the fact that both groups are considered "irregular migrants" makes them vulnerable to exploitation - although it should be noted that trafficked persons are not always "irregular migrants" while smuggled persons are. Thus, smuggling can easily become trafficking.

O'Connell Davidson (2013) reviewed how some policymakers, nongovernmental organization (NGO) activists, and academics see trafficking and smuggling. She made two distinctions: the first being that trafficking can be a process, whereas smuggling is a one-time transaction; and the second that trafficking involves "coercion and deception" while smuggling is "voluntary." However, drawing on numerous examples from practice, she discusses how smuggled migrants often, in an effort to finance their migration, acquire debts so great that they are required to accept working conditions that could very much be labeled as exploitative. At the same time, she argued that in some trafficking situations physical violence is not present, trafficked persons are fully aware of the type of work they will be conducting, and debts can be paid off in a short time frame of one to three years (O'Connell Davidson, 2013). Thus, the question remains: Wherein does the difference between smuggling and trafficking lie? And if we cannot provide a clear answer to this question, but want to remain true to the identified categories and definitions of trafficked and smuggled, how do those, in practical situations, responsible for determining the difference, decide how to categorize persons that could be deemed trafficked and smuggled? In such decision-making moments, is it the interest of the state or the interest of the individual that is primarily taken into consideration? Unfortunately, in looking at how border policies are implemented, it becomes evident that the interest of the state takes precedence over the interest of the individual.

\section{Current Debates in the Definition of Female Sex Trafficking}

In understanding and defining female sex trafficking, which is essentially the trafficking of women for purposes of sexual exploitation, we often rely heavily on the definition of human trafficking outlined previously. However, it should be noted that a clear definition of sexual exploitation is not available. In the literature, different authors provide various definitions. For instance, Segrave, Milivojevic, and Pickering (2009) defined sex trafficking as "trafficking of women into sexual servitude" (p. 1).

\section{The Issue of Consent}

According to those present during the drafting process (Doezema, 2005, 2010; Gallagher, 2001; Raymond, 2002) of the Protocol to Prevent, Suppress, and Punish Trafficking in Persons, Especially Women and Children, the primary issue of debate was the issue of consent and, particularly, "whether non-coerced, adult migrant prostitution should be included in the definition of trafficking" (Gallagher, 2001, p. 984). Thus, the definition of trafficking became a battleground between those who consider it possible for sex work to be a voluntary choice and those who consider prostitution to always be forced. The definition of sex trafficking would then depend on whether the international community would lean in favor of sex work or against prostitution.

The first camp promoting and protecting sex worker rights gathered under the Human Rights Caucus and was led by the Global Alliance Against Trafficking in Women (GAATW; Doezema, 2005). The second, pro-abolitionist camp was the International Human Rights Network, primarily led by the Coalition Against Trafficking in Women International (CATW; Raymond, 2002). According to CATW, "[T]here are different degrees, levels and extent of coercion, abuse and violence perpetrated against any woman or child at any particular time, which is critical to the individual. But all women who are in the sex industry are violated and sexually exploited" (O'Connor \& Healy, 2006, p. 5). 
For those belonging to the Human Rights Caucusor in general, those who believe sex work can be a choice - deeming consent irrelevant would mean infantilizing and disempowering the choices that adults - more specifically, women-make (Doezema, 1999, 2005, 2010). This camp claims such a tendency is already evident in the field of human trafficking and is particularly apparent when we look at images of the typical female victim: a woman who is deprived of her ability to make choices and completely lacks agency. In addition, such deprivation of the possibility to consent would clearly take away the option to work freely for many individuals who are currently sex workers by choice.

For the International Human Rights Network-or in general, those who consider all prostitution to be violence against women-recognizing consent as a possibility in the context of human trafficking would mean making a distinction between "deserving and undeserving" victims (Raymond, 2002, p. 494). It would put the burden of proving a situation of trafficking on the victim and provide a possible "out" for the trafficker, who can then claim that the person consented to the work (Raymond, 2002). According to this camp, sex work should not be grouped in with other types of labor because it most often involves some kind of harm to those who practice it, and the dangers of sex work are very different from the dangers of other kinds of labor. Finally, sex work cannot and should not be considered empowering for women, given that it is driven by male demand (Dempsey, 2010; Jeffreys, 2009; Miriam, 2005).

So how did this battle play out in the context of the protocol? As Gallagher (2010) explained, the protocol does not include the phrase "irrespective of the consent of the person." However, it does leave place for consent to be invalidated if any of the other means noted, such as coercion, of abduction, of fraud, or of deception are present (Gallagher, 2010, p. 27). In addition, Hoyle, Bosworth, and Dempsey (2011) have argued that including terms that have not been clearly defined, such as "abuse of power or of a position of vulnerability," makes it possible to make consent irrelevant in the future.

It is clear that the clash between the two camps is still being fought today, perhaps in particular because the definition of female sex trafficking does not clearly favor one side or the other. Thus, countries such as the United States, labeled by some as "neo-abolitionist," are in a position to continue to carry out the battle through, for example, finances (Soderlund, 2005), and in that context grants from the U.S. Agency for International Development (USAID) fund only those antitrafficking organizations that are clearly against prostitution (Overs \& Hawkins, 2011; Soderlund, 2005). Overs and Hawkins (2011) pointed out this kind of behavior is especially damaging to sex workers, because the NGOs that were crucial in offering health services to sex workers now have limited access to funding. Such policy, as well as a push to adopt an abolitionist stance within the protocol, gained substantial ground during the presidential terms of George W. Bush, who linked the moral grounds of his war on terror with a war against trafficking (Soderlund, 2005; Weitzer, 2007).

Studies have also been published showing that the legalization of prostitution is tied to persistent or increased levels of female sex trafficking (Huisman \& Kleemans, 2014; Kenyon \& Schanz, 2014; Marinova \& James, 2012). It is, however, important to recognize that quantitative studies seeking to show that legalization of prostitution leads to increased trafficking are questionable, as the numerical data available on prostitution as well as trafficking are far from reliable or complete (Cho, Dreher, \& Neumayer, 2013; Jakobsson \& Kotsadam, 2013).

Munro (2006) noted that despite the friendliness of some legislative systems to sex work, stigma persists. Thus, stigma, in combination with the pressure to register as a sex worker, as in the Netherlands, may be the real culprit for sex workers' choice to remain "illegal" and thus vulnerable to exploitation, even though they have the option of legality (Outshoorn, 2012). Hubbard, Matthews, and Scoular (2008) compared a number of legal systems as they pertain to sex work and prostitution and concluded that they may all have similar outcomes in that most drive visible sex work and prostitution away from the streets and eyes of society underground, where all involved are, once again, vulnerable to abuse.

Finally, there are those who propose a disengagement with this long-standing debate in favor of sex work and against prostitution (Barnhart, 2009; O'Connell Davidson, 2006; Wagenaar \& Altink, 2012). Some scholars note that the underlying factor in all discussions is the presence or absence of exploitation. Thus, they claim that efforts should focus on defining exploitation and distinguishing different levels of exploitation, as these should resolve many of the current debates and struggles played out in discussion surrounding the issue of sex trafficking. It can be argued that the strong ties among sex work, prostitution, and trafficking have their roots in the past, which is why they are not easy to overcome.

\section{History of the Definition of Female Sex Trafficking}

It is currently quite common to come across references to female sex trafficking as "modern-day slavery" in reports by not only media, international organizations, and governments, but also in the academic literature. One quite apparent reason for this is that human trafficking has its roots in White slavery. White slavery is understood as the "procurement by force, deceit, or drugs, of a white woman or girl against her will, for prostitution" (Doezema, 1999, p. 25). As Silvia Scarpa (2008) noted, at the start of the 20th century, numerous international conventions were adopted due to the sudden rise of White slavery. What is noticeable in the conventions, over time, is shifts in terminology from "white slave traffic" to "traffic in women and children." Finally, in the 
immediate predecessor of the 2000 protocol, namely the Convention for the Suppression of the Traffic in Persons and the Exploitation of the Prostitution of Others, which was introduced in 1949, we see "race, gender and age neutral terminology" (Scarpa, 2008, p. 52).

The pressure to address the issue of White slavery, and the manner in which it was addressed - namely by asking for the abolition rather than the regulation of prostitution-was the result of efforts on the part of feminist abolitionists, led by Josephine Butler (Scarpa, 2008). Thus, the 1949 convention took an abolitionist stance toward prostitution, which some say is why there was such a low number of signatories at the international level (Gallagher, 2010; Scarpa, 2008). It should be noted that today's CATW has its roots in the same abolitionist movement of the 1900s.

Another reason why trafficking is often equated with slavery can be found in the definitions of both. Bales (2012) defined contemporary slavery as "the total control of one person by another for the purpose of economic exploitation," noting that although slavery in the past was a matter of legal "ownership," "today it is a matter of having full control over a person through the use of violence" (pp. 5-6). Similarly, the previously mentioned definition of trafficking refers to "slavery or practices similar to slavery" as forms of exploitation or as end goals of the trafficking process; thus, one could contend that "slavery" is contained within the definition of trafficking (Gallagher, 2010).

It should be noted that some scholars claim that there are no data showing that White slavery was indeed a reality (Doezema, 1999). In fact, it seems to have coincided, as does present-day human trafficking, with a period of feminization of migration (Doezema, 1999). These scholars claim that the movement of women in order to work as prostitutes has in the past, as today, often functioned to create a "moral panic," resulting in the creation of the myth of "White slavery" (Doezema, 1999). Thus, White slavery has served as a tool for abolitionists to take away the ability of women to choose sex work, and thus restore the "moral order" of society (Bernstein, 2007; Doezema, 1999). These same scholars claim it is in the interest of such groups to use strong dichotomies, such as freedom and slavery, which translate into images of the whore or the innocent victim, to attract and secure public sympathy. In fact, some claim that if we look critically at the way in which trafficked persons are classified today, we will see that women who are not deemed "pure" enough or who have not shown remorse for their choices are not given the status of being trafficked. In addition, the stories which tend to reach the public and which are contained in the reports of international organizations are those of the beautiful victim who was unaware that she would be working as a prostitute, who repents and wants help to reform but practices no agency of her own and is left to the will of benevolent saviors (O’Brien, Carpenter, \& Hayes, 2013;
Saunders, 2005). In countries such as the United States, abolitionists are often joined by religious groups that seek to confine sex to the institution of marriage (Bernstein, 2007; Soderlund, 2005).

Taking all of this into consideration, regardless of the profile of the "victim," the nature of exploitation, or the scope of the issue, trafficking serves well to justify strict border controls and restrictions on migration, especially for female migrants. The current data on female sex trafficking, the problems that accompany estimations, as well as approaches to sex trafficking through the prism of security, migration, and human rights, are discussed in the next section.

\section{Estimations of the Numbers of Trafficked Persons}

The most commonly quoted estimate of the number of persons trafficked, provided by the ILO (2012), claims that 20.9 million persons are currently subjected to forced labor, of which $55 \%$ are women and girls, and $22 \%$ are forced into sexual exploitation. The ILO uses the "capture-recapture" method to produce the estimate, which has received significant criticism. Additional estimations are those provided by the Trafficking in Persons Report, published yearly by the U.S. State Department, which claims that 600,000 to 800,000 men, women, and children are subject to human trafficking annually, or a total of 27 million, a number also given by Kevin Bales (2012), an expert on modern-day slavery (U.S. Department of State, 2013).

However, all of these numbers are only estimates. UNODC has provided the most comprehensive data on cases identified as human trafficking in a report published in 2012. According to the UNODC, information was collected from throughout the world, primarily from government bodies, on 55,000 cases of trafficked persons. Of these cases, $59 \%$ were women, and $58 \%$ of all cases were situations of sexual exploitation. It should be noted that sexual exploitation is the dominant form of human trafficking in Europe, Central Asia, and the Americas. Thus, the same report cautions that the predominance of this form of human trafficking may be a result of better identification methods in these particular parts of the world or of this particular form of trafficking.

\section{Female Sex Trafficking: Security, Migration, and Human Rights}

There are three dominant approaches to the issue of sex trafficking; their primary relevance is not only what they offer in terms of theoretical discussions on trafficking but also the policies they suggest. Thus, trafficking is most commonly seen as an issue of state security, an issue of migration, or an issue of human rights. Each of the noted approaches and their policy implications, as well as criticism received, are discussed in the next sections. 


\section{Security}

Gallagher (2010), a prominent human-rights lawyer affiliated with the United Nations, recalls the outrage of colleagues when the issue of human trafficking was removed from the auspices of the United Nations human rights system and given to UNODC. However, in retrospect, Gallagher (2010) noted that it was the right decision, because the protocol would never have received the attention it has, had it stayed solely a human rights issue. Thus, the primary driver for pushing through the UN protocol was state security. Human trafficking was pegged as a transnational, organized criminal activity and, as such, a threat to each country and its people. Not only was it claimed that transnational criminal organizations were the primary culprits of the crime, it was also noted that profits from trafficking activities are used to finance conflicts and terrorism in various parts of the world (Goodey, 2003; Shelley, 2010).

The language used in the protocol, when speaking of criminalization versus assistance and protection, also makes obvious that the protocol is primarily a tool used for the protection of state security (Fitzpatrick, 2002; Gallagher, 2010; Lobasz, 2009). Article 5 of the protocol asks for the criminalization of human trafficking, noting that "each state party shall adopt" all measures deemed necessary to establish trafficking as a criminal offence (UNODC, 2003b, p. 2). However, Article 6-which addresses assistance and protection of persons trafficked and asks for the provision of housing, counseling, and information; medical, psychological, and material assistance; and employment, educational and training opportunities - adopts a softer language, noting "each state party shall consider" providing the noted services to persons trafficked (UNODC, 2003b, p. 3).

A criminalization and security approach to human trafficking has brought about primarily two types of policy responses from states: (a) stricter border controls and (b) raids of establishments where supposedly trafficked women are kept (Goodey, 2003). Both approaches have been the target of harsh criticism.

Researchers note the consequence of strict border controls is that it serves to push individuals wanting to migrate into the hands of actors who could potentially take advantage of them (Andrijasevic, 2003; Chapkis, 2003; Schaeffer-Grabiel, 2010; Skeldon, 2000; Väyrynen, 2003; Vijeyarasa, 2013). In other words, strict border controls may serve to make women migrants, especially sex migrants-women migrating with the primary purpose of seeking employment in the sex industrymore vulnerable to trafficking.

On the other hand, raids - which, granted, are more rarely used at present - are criticized for often being employed as a method for curbing prostitution rather than addressing sex trafficking. In addition, reports have been recorded in which the women who have been "saved" are abused by their "rescuers" (Amar, 2009; Lindstrom, 2004).

Interestingly, the security approach not only identifies traffickers as dangerous but also the person who is trafficked is identified as potentially dangerous for the receiving country and its people. Aradau (2004) elaborated in detail on how the international politics of "pity," inspired by idealized versions of the pure, innocent, and unknowing victim of trafficking, have been transformed into politics of "risk." In other words, women who have been abused can be seen as potential future abusers. Thus, the safest strategy for receiving countries is to ship these women back to where they came from. It is in this way that repatriation and deportation have been justified to the public (Muftić, 2013; Segrave et al., 2009). Thus, these women, while considered to deserve pity, are nonetheless construed as different, as the "other" (Berman, 2003; Goodey, 2003; Todres, 2009), with devious practices and questionable morals, and are therefore best kept outside of borders (Aradau, 2004). In the name of protecting its citizens, the state regains control and creates a new purpose for its existence (Berman, 2003).

\section{Migration}

The current international emphasis on the issue of human trafficking is said to have coincided with a period of increased female migration. Economic crisis, conflict, a sense of adventure, and curiosity have prompted many women to cross borders in search of economic means for themselves or their families, or simply in search for a better life (Mai, 2013). However, it has been suggested that it may be this increased willingness to migrate which makes women more vulnerable to abuse and which feeds the supply side of human trafficking. Researchers have attempted to strengthen this claim by linking high migratory movements and developed migrant networks in destination countries to a rise of human trafficking (Cho, 2013). These links have then prompted policies such as tighter border controls and campaigns that seek to discourage the migration of women (Nieuwenhuys \& Pécoud, 2007).

Once again, strict border controls and antitrafficking campaigns have received strong criticism. Some claim that the issue of human trafficking is grossly exaggerated so that it can be used as a tool to curb female migration, in particular migration for the purpose of sex work (Haynes, 2004; Pickering \& Ham, 2014). Information campaigns launched by actors such as the International Organization of Migration subscribe to the image of the innocent, unknowing female victim versus the evil male trafficker (Andrijasevic, 2007). Trafficking is thus often equated with prostitution, and potential female migrants are given the impression that, should they attempt to cross borders, they may end up being sex slaves. Anecdotes told in prevention and information leaflets speak 
of women applying for jobs in the service sector but unknowingly and unwillingly ending up in prostitution. Thus, once again, this touches on the issue of consent. The stories of women who knowingly seek employment in the sex sector are not found in information pamphlets and campaigns (Andrijasevic, 2007).

Furthermore, this group is not always visible. The extent to which these women are labeled as "trafficked" or as "illegal immigrants" often depends on the needs of the country in question at the time. For instance, Brennan (2014) pointed out that when Argentina wanted to show that it was making progress in its antitrafficking policies by increasing its victim identification efforts, it grouped together trafficked persons with immigrant sex workers and labeled all as trafficked. In contrast, Brazil does not make a distinction between trafficking and prostitution. Thus, all women involved in the sex industry in Spain coming from Brazil, whether they are persons trafficked or immigrant sex workers, are labeled as trafficked (Piscitelli, 2012).

As some suggest, one way to resolve the current crisis would be to focus not solely on trafficking but also on migration rights and citizenship rights of illegal immigrants and illegal sex workers, as well as labor rights for all sex workers (Anderson \& Andrijasevic, 2008; Andrijasevic, Aradau, Huysmans, \& Squire, 2012; Chapkis, 2003; Skeldon, 2000). In other words, it is argued that attempts should be made toward recognizing sex work as a form of labor and making it possible for women to safely perform it either in their home countries or through working visas across borders. This, it is claimed, would constitute a true approach to trafficking through migration and would address the current vulnerability that illegal migration creates for sex workers (Agustín, 2006).

\section{Human Rights}

The common framing of sex trafficking as modernday slavery and an emphasis on the pervasiveness of violence has made it increasingly possible to approach the issue of female sex trafficking through the lens of human rights (Saunders, 2005). The reasoning is simple: As basic human rights are broken by the practice of sex trafficking, the human rights approach is crucial to addressing the needs of those affected.

The protocol, and the already noted language surrounding the topics of assistance and protection of victims, was seen as a major failure for the human rights camp (Fitzpatrick, 2002). However, despite the soft language, in practice the basic services that should be available to those trafficked are being offered. In some cases, this happens through the state; in others, through international NGOs. Several of the noted provisions are the nondiscriminatory application of antitrafficking law, noncriminalization of persons trafficked, possibility for financial compensation, protection of persons trafficked, possibility to stay in receiving countries, and some basic services such as medical and mental health care and shelter (Jordan, 2002).

It is worth noting several researchers have emphasized that not all violations that happen within a trafficking experience are necessarily human-rights violations. Some situations fall within the current definition of trafficking but are not a violation of human rights. These are more likely to be violations of labor rights. One such example is when a sex worker shares her fee with an agent (Munro, 2008; Shamir, 2012). Therefore, the framing of the issue of trafficking as a matter of human rights should not be taken for granted.

Finally, in addition to the three approaches described, some researchers have noted a need to look at some of the systemic factors that may be responsible for the existence of female sex trafficking (Hua \& Nigorizawa, 2010; Limoncelli, 2009; Todres, 2005; Wong, Holroyd, Chan, Griffiths, \& Bingham, 2008). Instead of discussing consent and whether or not sex work can be voluntary, we should work toward creating situations in which women always have choices and opportunities; thus, efforts should be made to eliminate situations in which sex work is an economic imperative. Therefore, it is claimed, policies should address poverty, educational opportunities for women, and gender discrimination (Hua \& Nigorizawa, 2010; Limoncelli, 2009; Todres, 2005; Wong et al., 2008).

\section{Actors: Persons Trafficked, Traffickers, Clients, and Service Providers}

The following section focuses on the primary actors involved in sex trafficking. However, although a description of the prevailing profiles of each actor, as found in the literature, is given, it should be noted that the characteristics of each actor are not exhaustive. There is no such thing as a "typical" profile of a person trafficked, trafficker, client, or service provider.

\section{Trafficked Persons}

The primary targets of sex trafficking are women or, as Vijeyarasa (2013) eloquently stated, "trafficking is gendered, and the gender is female" (p. 1024). Poverty and being unemployed prior to the trafficking experience are common characteristics attributed to trafficked women (Acharya, 2010; Hughes, 2000; Silverman et al., 2007; Vindhya \& Dev, 2011). Women trafficked are often described as having low levels of education and as coming from difficult family situations where they suffered some kind of physical or sexual violence (Acharya, 2010; Hughes, 2000; Reid, 2012; Silverman et al., 2007; Vindhya \& Dev, 2011; Zimmerman, Kiss, Hossain, \& Watts, 2009). However, although these characteristics are frequently mentioned, they are by 
no means the rule. Many women do not come from a situation of extreme poverty but end up being trafficked when looking for a way to make more money-often by accepting sex work (Pajnik, 2013; Stoecker, 2000; Surtees, 2004). Some women simply desire a lifestyle they have heard about from other female migrants who work abroad or a wealthy lifestyle as presented in magazines and on television shows, such as Brazilian soap operas and so-called Cinderella stories (Vijeyarasa, 2012, 2013). In many cases, the women are relatively well educated but dissatisfied with the material benefits of their professions (Pajnik, 2013; Stoecker, 2000; Surtees, 2004).

\section{Traffickers}

One of the primary reasons that antitrafficking legislation was enacted at the international level was because perpetrators of human trafficking have been framed as highly organized, transnational criminal groups and networks (Shelley, 2010; Surtees, 2008b). For example, focusing on traffickers in Southeast Europe, Surtees (2008c) noted that these organized crime groups working across countries comprise members of various nationalities and ethnicities. However, extensive recent research has failed to make connections between transnational organized crime and human trafficking (Chin \& Finckenauer, 2011; Piscitelli, 2012; Zhang, 2011).

Pimps are commonly mentioned as actors responsible for sex trafficking (Chin \& Finckenauer, 2011; Marcus, Horning, Curtis, Sanson, \& Thompson, 2014; Verhoeven, van Gestel, de Jong, \& Kleemans, 2013; Zhang, 2011). Because sex trafficking can be based on an intimate relationship between the woman and her pimp, sex trafficking can be seen as a crime of "relational nature" (Verhoeven et al., 2013). In this context, the man initially establishes his status as a boyfriend and subsequently controls the woman through emotions, intimidation, or violence. Overall, however, it is noted that pimps are not connected with organized crime in most cases. In fact, the daily activities of a pimp appear to be highly individualized and thus do not require the involvement of organized crime. On the other side, the activities of a pimp are not very profitable, thus making that role unattractive for most organized crime groups (Zhang, 2011).

It should be noted both men and women can be pimps. Studies find female pimps to be predominant in high-end escort services (Zhang, 2011), but they can also be found in other roles. One such role is that of recruiter. Women can act as recruiters, in many cases, while themselves being sex workers or victims of sex trafficking. Female recruiters have also been found to frequently work together with a man who, after the recruitment by the women, is responsible for transportation (Surtees, 2008b). It has also been noted that women who have managed to create a good living for themselves as sex workers sometimes offer novices start-up loans. For example, Piscitelli (2012) reported that women from Brazil who had established themselves as sex workers in Spain sometimes offered to pay for the trip and start-up of other Brazilian women who knowingly wanted to perform sex work. Naturally, interest rates on such loans tend to be excessive. The irony of these situations is that, although these established sex workers could be considered traffickers, according to Brazilian law they are considered victims of trafficking themselves because they are sex workers in a foreign country (Piscitelli, 2012).

Perhaps the most notorious role of female traffickers is that of the madam (Chin \& Finckenauer, 2011; Leman \& Janssens, 2013; Mancuso, 2014; Siegel, 2012). The most common case noted is that of the Nigerian madams, who are usually former sex workers themselves who have moved up and created their own establishments that recruit and employ other women. Women from Nigeria are then either sold by their family or ask for a loan from the madam themselves in order to leave Nigeria and work as prostitutes throughout Europe. Interestingly, the way in which the madam ensures repayment of debts is by binding the woman and her family through voodoo and juju rituals. A recent study, performing a social network analysis to determine the role of different actors in a trafficking case in Italy, found the role of the madam to be central to the trafficking process (Mancuso, 2014).

Chin and Finckenauer (2011) noted a number of additional actors who are often attributed the role of trafficker. Actors who loan money to a woman or her family to enable her to travel to another country and conduct sex work are usually also referred to as "agents" and are considered to have ownership of the woman until she repays her debt. Some other actors noted are the "jockeys," who are responsible for the physical transfer of the woman to her place of work; "fake husbands," who marry women who want to travel to other countries for sex work; and "mommies," who introduce women to clients; in addition to escort agency owners and brothel owners (Chin \& Finckenauer, 2011).

Finally, it should be noted that, in many cases, traffickers justify their participation in trafficking by using a variety of arguments. This is known as a process of neutralization (Copley, 2014). Copley (2014) charted different strategies by which this is done. Some traffickers attempt to minimize the exploitation by seeing themselves as helping rather than hurting the person trafficked. Others dehumanize the victims, seeing them as objects rather than people. Another strategy entails shifting the blame for the occurrence of trafficking to, for instance, corruption. A final strategy outlined by Copley (2014) is one in which traffickers call on the necessity of trafficking in certain situations, such as the need to supply women to soldiers during a war. 


\section{Clients}

The actor least known within the process of sex trafficking is the client. It is extremely difficult to distinguish between clients of voluntary sex workers and clients of trafficked persons. A study performed by Anderson and O'Connell Davidson (2003), focusing on clients of sex workers in Denmark, Thailand, India, and Italy, has shed some light on how clients view the purchase of sexual services from a person who is trafficked. This study found that those clients who viewed prostitutes as objects and paying for sex as a trade tended to like exercising control in these situations and were thus more likely to seek out sex workers in vulnerable situations (Anderson \& O'Connell Davidson, 2003). In a study by Todres (2009), the authors claimed that discrimination based on race, ethnicity, or class is the driving force behind certain men purchasing sex from certain groups of women. Preference for trafficked women comes about because the women are seen as an "other" and thus looked down upon, and their vulnerability and submissiveness is seen as an attractive trait.

Other literature has explored specific kinds of clients. Some studies have placed the onus for increased trafficking on soldiers and peacekeepers who have, as a group, increased the demand for sex workers (Allred, 2006; Haynes, 2004). The claim is that, when the supply of voluntary sex workers insufficiently meets demand, the additional sex workers needed are provided through trafficking. An aggravating factor in such situations is that these actors usually have immunity in the country where they are stationed and thus cannot be held accountable for purchasing sex from victims of trafficking despite adequate legislation being in place (Allred, 2006).

The final circumstance that generates a discussion of clients and the demand side of sex trafficking is sporting events. Soccer's World Cup, cricket tournaments, Super Bowl games, and the Olympics have all been identified, primarily by international organizations, governments, and the media, as occasions that potentially increase the demand for sex workers and thus sex-trafficking victims. However, increases in the incidence of sex trafficking in these situations has been widely debated (Bonthuys, 2012; Deering et al., 2012; Gould, 2010). Roe-Sepowitz, Gallagher, and Hickle (2014), in their study of sex trafficking and sex-worker demand during the 2014 Super Bowl, demonstrated an increase in the number of advertisements offering sexual services around the time of the Super Bowl. However, they failed to show any fluctuation or possible increase in demand during the actual Super Bowl, as opposed to any other point in time (Roe-Sepowitz et al., 2014). Both Bonthuys (2012) and Gould (2010) focused on the soccer World Cup that took place in 2010 in South Africa and found that media reports and antitrafficking campaigns at the time estimated that 40,000 persons were trafficked for the event. Both authors also found the same unsubstantiated number of estimated trafficked persons in media on the 2006 World Cup in Germany. Gould (2010) examined whether there indeed were reports of an increase in human trafficking prior to and following the 2010 World Cup and found no such increases. Naturally, international organizations and governments credit the lack of increase in human-trafficking cases during sporting events to the implemented antitrafficking campaigns (Gould, 2010). It should be noted that the lack of evidence on the impact sporting events can have on human trafficking is potentially because it is difficult to properly assess changes in numbers of people trafficked in general and that the short period of time allotted to such sporting events makes this even more difficult.

\section{Service Providers}

The final actors relevant to the issue of sex trafficking are service providers. Unfortunately, there is a paucity of research focusing on the various service providers, such as the social workers, psychologists, lawyers, police, and doctors who in some way have had contact with victims of trafficking, which tends to occur after identification.

However, a recent study has noted social workers as the most important service providers for victims of trafficking (Busch-Armendariz, Nsonwu, \& Heffron, 2014). In fact, this study identified the social worker as the central figure for the trafficking victim for three main reasons. First, social workers are the coordinators of all interactions not only between other service providers and a trafficked person but also among all other service providers involved in a case. Second, social workers are usually the ones responsible for building and establishing trust with victims. Third, social workers are usually found to be culturally sensitive and well trained to deal with different groups of victims and thus are, through the application of the ecological model, the most helpful people for victims immediately after identification.

\section{The Process of Female Sex Trafficking}

This section places the different actors within the process of sex trafficking. We discuss common methods for recruitment used by traffickers, common characteristics of the trafficking experience, common means by which trafficked persons are identified, and common processes of recovery and (re)integration that follow identification.

\section{Recruitment}

There are two relevant aspects of the recruitment process, namely the person or persons doing the recruiting and the method of recruitment. The method 
of recruitment is visibly connected to the vulnerability of the target.

One commonly mentioned recruiter and method of recruitment is the pimp who gains trust and thus controls the woman by becoming her boyfriend and, in certain situations, by offering marriage (Crawford \& Kaufman, 2008; Deshpande \& Nour, 2013; Di Tommaso, Shima, Strøm, \& Bettio, 2009; Hom \& Woods, 2013; Verhoeven et al., 2013; Vindhya \& Dev, 2011). The vulnerability of the person trafficked in these situations may be the need for affection and love (Hom \& Woods, 2013). Preying on this vulnerability, the pimp establishes his role as a boyfriend (Verhoeven et al., 2013) and shortly thereafter asks the woman to perform sex work to support the couple materially. The pimp often uses intimidation and violence to control the woman (Verhoeven et al., 2013). This process has been termed "pimp enculturation" by Hom and Woods (2013).

Another commonly used method of recruitment is one in which a woman is offered employment. With this method, the trafficker preys on the woman's economic vulnerability or, alternatively, simply plays into her desire to migrate (Crawford \& Kaufman, 2008; Di Tommaso et al., 2009; Hughes, 2000; Jones, Engstrom, Hilliard, \& Sungakawan, 2011; Silverman et al., 2007; Surtees, 2008b; Vindhya \& Dev, 2011). In these situations, the recruiter may be someone the woman knows personally, such as a friend, or the recruiter could be a stranger (Di Tommaso et al., 2009). In addition, this method of recruitment can occur through the Internet, $\mathrm{TV}$, or newspaper advertisements (Di Tommaso et al., 2009; Hughes, 2000). In these cases, the employment offered is usually babysitting, serving or being a hostess in the food and beverage industry, or dancing ( $\mathrm{Di}$ Tommaso et al., 2009; Hughes, 2000; Surtees, 2008b). In some cases, recruiters are open about the fact that the employment offer is for sex work (Di Tommaso et al., 2009; Jones et al., 2011; Molland 2010, 2011; Piscitelli, 2012), and sometimes the recruiter is a sex worker herself (Molland, 2011; Piscitelli, 2012). Consequently, when women knowingly accept sex work, the form of exploitation generally pertains to working conditions (Jones et al., 2011) or to the division of profits between the sex worker and the recruiter (Molland, 2010). For example, Jones and colleagues (2011) outlined how women from Thailand were offered transfer to Japan in order to work in the sex industry, but on arrival they were informed of debt incurred, their documentation was taken away from them, and they had no control over the number of customers or type of sex to be provided until the debt was paid off.

\section{Trafficking Experience}

Although each trafficking experience has its own unique characteristics, some commonalities have been reported. For example, Zimmerman and colleagues
(2009), in their study that focused on 192 women receiving posttrafficking services in Belgium, Bulgaria, the Czech Republic, Italy, Moldova, Ukraine, and the United Kingdom, found that the trafficking experience lasted from one day to three months for $33.2 \%$ of the women, three to six months for $19.3 \%$, six months to a year for $19.8 \%$ of the women, and longer than a year for $18.8 \%$ of the women. Oram and colleagues (2012), in a study that explored 120 cases of trafficked women returned to Moldova, found that $67.5 \%$ were trafficked for more than six months and $27.5 \%$ were trafficked for more than a year. Vindhya and Dev's (2011) study, which looked at 78 case studies of trafficked women in India, found an average duration of the trafficking experience to be two years.

In terms of working conditions, studies have reported a lack of choice with regard to client selection, types of sexual services offered, and use of condoms (Di Tommaso et al., 2009; Jones et al., 2011). Also, Di Tommaso and colleagues (2009) established that the average sex-trafficked women in their study worked every day of the week, 13 hours a day, with an average of five clients per day (Di Tommaso et al., 2009). Acharya (2010) documented more than eight clients per day for $43 \%$ of the victims in that study. In addition, studies have noted that sex-trafficked women often have limited or no freedom of movement and limited or no access to medical care (Di Tommaso et al., 2009; Jones et al., 2011; Zimmerman et al., 2008). Physical and sexual violence during the trafficking experience has also been reported frequently and can include rape, gang rape, being beaten with objects, and being burned with cigarettes (Acharya, 2010; Crawford \& Kaufman, 2008; Di Tommaso et al., 2009; Jones et al., 2011; Zimmerman et al., 2008).

The trafficking experience has also been found to be accompanied by physical and mental health symptoms that can have short-term or long-term health consequences. Physical symptoms documented include headaches, tiredness, and dizziness; back, stomach, and pelvic pain; tooth pain; a loss of appetite; physical injuries; unsafe abortions; and sexually transmitted infections, including HIV (Collins et al., 2013; Konstantopoulos et al., 2013; Oram et al., 2012; Wirth, Tchetgen, Silverman, \& Murray, 2013; Zimmerman et al., 2008). Decker, McCauley, Phuengsamran, Janyam, and Silverman (2011) conducted a study of female sex workers in Thailand and found those who entered sex work through trafficking to be at greater risk for sexual violence upon initiation and violence in the workplace, and to be more likely to have abortions and not use condoms, or use them inconsistently, which increased their vulnerability to HIV infection.

Mental health symptoms reported include posttraumatic stress disorder, depression, and anxiety (Abas et al., 2013; Chudakov, Ilan, Belmaker, \& Cwikel, 2002; Konstantopoulos et al., 2013; Zimmerman et al., 2008). 
Sex trafficking victims are also more likely than victims of other types of trafficking to use alcohol and drugs (Lyneham \& Larsen, 2013).

\section{Identification}

Successful identification has been defined as a "situation in which antitrafficking professionals were able to identify individuals as trafficked (or potentially trafficked) in an appropriate, sensitive and timely fashion, and to provide suitable options for referral and assistance at home or abroad depending on the situation" (Brunovskis \& Surtees, 2012b, p. 16). Brunovskis and Surtees (2012b) noted the main methods through which identification of persons trafficked for sexual exploitation occurs, pointing out that identification mainly happens in the country of exploitation. The authors emphasized that most commonly it was found that the victims themselves recognized their situation as one of trafficking and thereafter sought out actors who could help them escape their situation (Brunovskis \& Surtees, 2012b). Thus, Richards and Lyneham (2014) pointed to neighbors as one category of actors whom victims sometimes approached for help. Another way of identification is by police, often through raids (Amar, 2009; Brunovskis \& Surtees, 2012b). Finally, NGOs, social-assistance agencies, as well as persons who are sex workers themselves may assist in the identification and escape of women from a situation of trafficking (Amar, 2009; Brunovskis \& Surtees, 2012b; Richards \& Lyneham, 2014).

\section{Recovery and (Re)integration}

Once a trafficked person has been identified, the process of (re)integration is initiated. (Re)integration of persons who have been trafficked has been defined as "the process of recovery and socio-economic inclusion following a trafficking experience; it includes settlement in a safe and secure environment, access to a reasonable standard of living, mental and physical well-being, opportunities for personal, social and economic development and access to social and emotional support" (Surtees, 2010, p. 24). Early on in this process, focus is usually placed on dealing with the physical and mental health consequences of the trafficking experience, as well as feelings of fear and shame (Surtees, 2010). These immediate needs are usually addressed by placing identified trafficked persons in a shelter where women are offered counseling services, medical checkups, and psychological consultation (Bjerkan, 2005; Brunovskis \& Surtees, 2008; Jayagupta, 2009; Surtees, 2010; Vijeyarasa, 2010). Unfortunately, shelter environments have received significant criticism, the contention being that shelters can have a negative impact on victims. In fact, some researchers have indicated that shelters limit the basic freedoms of the people they seek to help and provide very little privacy (Jayagupta, 2009; Surtees, 2008a; Vijeyarasa, 2010) while at the same time attempting to "reform" victims and turn them into "good girls" by teaching them how to dress and act modestly, as has been documented in Southeast Europe (Brunovskis \& Surtees, 2008). In this context, prostitution is seen as a form of pathology (Brunovskis \& Surtees, 2008).

Given that most women eventually return to their country of origin, the next steps in the (re)integration process are economic independence and resocialization (Brunovskis \& Surtees, 2012a; McIntyre, 2014; Pandey, Tewari, \& Bhowmick, 2013; Van Hook, Gjermeni, \& Haxhiymeri, 2006). Often, women are offered a variety of vocational training courses and provided with assistance in seeking and obtaining employment (Bjerkan, 2005). Unfortunately, training programs have not always been found to be helpful, as some are poorly aligned with current job market demands (Jayagupta, 2009; Pandey et al., 2013) and others have been found to be severely gendered (Kelly, 2003). Additional methods offering potential independence and economic viability that have been reported include micro credit and social businesses (Surtees, 2012; Van Hook et al., 2006). Recognizing the importance of economic independence, calls have been made for greater emphasis on providing financial compensation to victims for the time they spent in a trafficking situation (Kim \& Hreshchyshyn, 2004).

Finally, successful recovery and (re)integration of trafficking victims includes a focus on the social environment and, when possible, reunification and reconciliation with family (Brunovskis \& Surtees, 2012a; Pandey et al., 2013; Vijeyarasa, 2010). In their work focusing on returned trafficked persons from Moldova, Brunovskis and Surtees (2012a) established that conflicts between trafficked persons and their families tend to arise when migration expectations are not realized. They noted that ongoing financial difficulties and stigma related to the trafficking experience place additional strain on family relations. In addition, a variety of other factors can inhibit reunification and reconciliation with family. For example, victims may become disappointed when family members fail to meet their expectations with regard to support provision; relationships with children may be hard to reestablish when children harbor resentment and feelings of abandonment; and relationships with partners may be strained by feelings of jealousy (Brunovskis \& Surtees, 2012a).

It should be noted that, to date, no studies exploring the long-term health, economic, and social consequences of sexual exploitation have been conducted. It is therefore difficult to determine how these health, economic, and social factors interact over time and the degree to which the recovery and (re)integration services offered positively or negatively impact the well-being of a person trafficked. 


\section{Recommendations for Future Research}

Given this review of the literature, we contend there are two concepts that require further investigation and clarification if we are to adequately address the issue of female sex trafficking. These issues are vulnerability and exploitation. This section discusses how these two concepts play a role in all aspects of the sex trafficking process and outlines how important they are for not only the prevention of sex trafficking but also for interventions that seek to improve the lives of those affected by trafficking.

Currently, and as stated previously, the issue that appears to take precedence in sex trafficking debates is the presence or absence of consent and the relevance of consent in identifying trafficking victims (Barnhart, 2009; O'Connell Davidson, 2006; Wagenaar \& Altink, 2012). The concept of consent is often used to label a situation as one of smuggling or as one of trafficking; it is also used to argue that sex work should be recognized as a form of labor or as abuse. We claim that arguments and discussions surrounding the issue of consent seem endless and seem to continue without any resolution. We further contend that resolution may come if, as suggested by others, attention is refocused away from consent and toward defining what is meant by exploitation (Barnhart, 2009; O'Connell Davidson, 2006; Wagenaar \& Altink, 2012). Determining a threshold beyond which certain types of behavior are considered exploitation, be it economic, physical, or mental, is crucial. Only after the concept of exploitation is clearly defined will we be able to easily determine if a person can and should be considered as trafficked. Some may claim that it is impossible to develop a clear definition of exploitation as it necessarily brings us back to issues of consent. This vicious circle may well be escaped if we add to the definition of exploitation the concept of vulnerability. Previous research has made evident that what all persons trafficked appear to have in common is that they all entered trafficking experiences through some form of vulnerability (see Recruitment section), whether it be a dire economic situation or simply a need to belong and receive affection. Whatever the case, the form of vulnerability experienced by a victim of sex trafficking may be crucial in determining the form and extent of the exploitation that follows.

To be able to identify how vulnerability and exploitation interact, and perhaps also to determine the severity of a trafficking experience, we must explore how persons trafficked recover and (re)integrate following trafficking experiences, in the immediate short-term as well as the long-term process. In addition, it is important to investigate situations in which women are trafficked within their own country of origin versus situations where women are trafficked abroad but return to their country of origin, as well as situations in which women are trafficked abroad and remain in the country of identification. Looking at the long-term consequences of recovery and (re)integration processes, whereby initial vulnerability is linked to forms of exploitation, which are then connected to various interventions following identification, may allow us to effectively appraise the success or failure of interventions and thereby allow the delineation of a variety of trafficking experiences. These experiences can then be classified according to their severity and, it is hoped, used to further clarify and define what exploitation is, while at the same time distinguishing sex trafficking from smuggling, prostitution and sex work, and cases of female migration. Clearly, future research that focuses on the long-term effects of recovery and (re)integration processes among female victims of sex trafficking is imperative.

However, for any research to be relevant to the field of female sex trafficking it needs to be recognized as worthwhile and applicable by actors dealing with the issue on the ground. For this to happen, research must have a clear functional significance. Learning how vulnerability ties in with exploitation and long-term recovery and (re)integration can be of great use in not only prevention but also detection and recovery and (re)integration efforts. A comprehensive understanding of the variety of vulnerabilities that could lead to sex trafficking can help practitioners design more effective prevention and intervention programs that better serve victims of sex trafficking. Such programs should be theory- and evidence-based (Bartholomew, Parcel, Kok, Gottlieb, \& Fernández, 2011) and developed in close collaboration among program developers, researchers, trafficked persons, and relevant parties for implementation (Bos, Schaalma, \& Pryor, 2008). Such interventions should also target different levels of intervention, such as intrapersonal, interpersonal, community, and (inter)national levels (Bos, Pryor, Reeder, \& Stutterheim, 2013).

\section{Conclusion}

We set out to explore the current academic research and conceptual debates with regard to female sex trafficking, compile the existing information in a comprehensive way, and identify knowledge still lacking. Based on the overall themes discussed here, several concluding remarks and final recommendations for future research can be made; such research can serve to help policymakers address and tackle human trafficking in addition to assisting those who are victims of trafficking.

First, it can be noted that most of the literature available in the field of human trafficking is highly polemic rather than academic. This is due to persistent ongoing debates and disagreement in regard to the definition of human trafficking. Although such literature is necessary and should be further produced to reflect the main discussions from the field, emphasis should also be placed 
on academic research, which currently is greatly lacking. This challenge could possibly be overcome by adopting a more interdisciplinary approach to the issue of sex trafficking and, where possible, basing polemic discussions on results gained from research in a variety of fields such as economics, law, psychology, sociology, and medicine.

Second, most of the academic research on human trafficking available is qualitative rather than quantitative. This is likely attributable to the fact that human trafficking is a sensitive topic and an illicit activity. Recruiting the kind of sample sizes necessary for adequate power in quantitative studies is almost always infeasible. Researchers should thus approach efforts to use quantitative methods in this field with considerable reservation.

Third, gray literature, often written in the form of reports, tends to be used quite frequently by policymakers. Unfortunately, in gray literature, the methodology applied is often unclear or undisclosed, which can lead to misconceptions about human trafficking. We therefore recommend the inclusion of academics in the production of such reports.

Fourth, there has been a multitude of disagreements regarding the interpretation of the concept of human trafficking, from the very conception of the definition of human trafficking up to the present. It may be time to accept that the explanation of human trafficking has been deliberately left as is to offer greater flexibility of use when needed in the field. We feel that it is not currently the time to call for changes or revisions to the definition, but rather we should attempt to better understand the terms that are used within it, starting with vulnerability and exploitation. Academia would be in the best position to make this contribution to the field of human trafficking.

Fifth, when it comes to border controls and migration, current research as well as policy seems to indicate that a choice has to be made, either for or against strict border controls, and for or against freedom of migration. However, research does not reflect such clear-cut solutions. Relatively speaking, for every article that states one position, there is a counterpart that comes to opposing conclusions. Additional research is therefore needed to show the extent to which checks at the border help or hurt the people they claim to protect.

Sixth, traffickers and clients are still very much a black box. Debates in regard to the definition of a trafficked person have been ongoing. It seems that the definition of a trafficker is also unclear. When does a woman who was initially trafficked but thereafter chose to remain in sex work and now charges other women in sex work for protection cease to be a victim and become a perpetrator? There may be some information and research in regard to clients of sex workers, but very little is known about those persons who purchase the services of trafficked individuals. In regard to both traffickers and clients, there are certain sources of information and methodologies of research that have not been fully utilized, such as criminal investigation reports in possession of the police and social-network analyses.

There is significant literature on the health consequences of human trafficking. However, we must ask how health, social, and economic factors linked to recovery and (re)integration interact, particularly in the long run. Financial need seems to be one of the primary drivers of vulnerability to trafficking, but we need to know more about the role economic necessity plays in decision making among trafficked persons after their trafficking experience, as well as the importance of financial compensation for their recovery.

Finally, female sex trafficking appears to be a polarized field in which policymakers as well as researchers feel compelled to uphold one extreme position or another. However, based on the literature reviewed, we contend what is most necessary is research that, regardless of direction of the conclusions, is based on sound scientific evidence above all else.

\section{References}

Abas, M., Ostrovschi, N. V., Prince, M., Gorceag, V. I., Trigub, C., \& Oram, S. (2013). Risk factors for mental disorders in women survivors of human trafficking: A historical cohort study. BMC Psychiatry, 13, 1-11. doi:10.1186/1471-244X-13-204

Acharya, A. K. (2010). Feminization of migration and trafficking of women in Mexico. Revista de Cercetare şi Intervenţie Socială, $30,19-38$.

Agustín, L. (2006). The disappearing of a migration category: Migrants who sell sex. Journal of Ethnic and Migration Studies, 32, 29-47. doi:10.1080/13691830500335325

Allred, K. J. (2006). Peacekeepers and prostitutes: How deployed forces fuel the demand for trafficked women and new hope for stopping it. Armed Forces and Society, 33, 5-23. doi:10.1177/ 0095327 X06288803

Amar, P. (2009). Operation princess in Rio de Janeiro: Policing "sex trafficking," strengthening worker citizenship, and the urban geopolitics of security in Brazil. Security Dialogue, 40, 513-541. doi:10.1177/0967010609343300

Anderson, B., \& Andrijasevic, R. (2008). Sex, slaves, and citizens: The politics of anti-trafficking. Soundings, 40, 135-145.

Anderson, B., \& O'Connell Davidson, J. (2003). The demand side of trafficking: A multi-country study. Stockholm, Sweden: Save the Children.

Andrijasevic, R. (2003). The difference borders make: (Il)legality, migration, and trafficking in Italy among Eastern European women in prostitution. In S. Ahmed, C. Castaneda, A. Fortier, \& M. Sheller (Eds.), Uprootings/regroundings: Questions of home and migration (pp. 251-272). New York, NY: Berg.

Andrijasevic, R. (2007). Beautiful dead bodies: Gender, migration, and representation in anti-trafficking campaigns. Feminist Review, 86, 24-44. doi:10.1057/palgrave.fr.9400355

Andrijasevic, R., Aradau, C., Huysmans, J., \& Squire, V. (2012). European citizenship unbound: Sex work, mobility, mobilisation. Environment and Planning D: Society and Space, 30, 497-514. doi: $10.1068 / \mathrm{d} 10210$

Aradau, C. (2004). The perverse politics of four-letter words: Risk and pity in the securitisation of human trafficking. Millennium Journal of International Studies, 33, 251-277. doi:10.1177/ 03058298040330020101 
Aronowitz, A. A. (2001). Smuggling and trafficking in human beings: The phenomenon, the markets that drive it, and the organisations that promote it. European Journal on Criminal Policy and Research, 9, 163-195. doi:10.1023/A:1011253129328

Bales, K. (2012). Disposable people: New slavery in the global economy. Berkeley, CA: California University Press.

Barnhart, M. H. (2009). Sex and slavery: An analysis of three models of state human trafficking legislation. William and Mary Journal of Women and the Law, 16, 83-131.

Bartholomew, L. K., Parcel, G. S., Kok, G., Gottlieb, N. H., \& Fernández, M. E. (2011). Planning health promotion programs: An intervention mapping approach (3rd ed.). San Francisco, CA: Jossey Bass.

Berman, J. (2003). (Un)popular strangers and crises (un)bounded: Discourses of sex trafficking, the European political community, and the panicked state of the modern state. European Journal of International Relations, 9, 37-86. doi:10.1177/ 1354066103009001157

Bernstein, E. (2007). The sexual politics of the "new abolitionism." Differences, 18, 128-151. doi:10.1215/10407391-2007-013

Bjerkan, L. (2005). A life of one's own: Rehabilitation of victims of trafficking for sexual exploitation. Oslo, Norway: Allkopi AS.

Bonthuys, E. (2012). The 2010 football World Cup and the regulation of sex work in South Africa. Journal of Southern African Studies, 38, 11-29. doi:10.1080/03057070.2012.642723

Bos, A. E. R., Pryor, J. B., Reeder, G. D., \& Stutterheim, S. E. (2013). Stigma: Advances in theory and research. Basic and Applied Social Psychology, 35, 1-9. doi:10.1080/01973533.2012. 746147

Bos, A. E. R., Schaalma, H. P., \& Pryor, J. B. (2008). Reducing AIDS-related stigma in developing countries: The importance of theory- and evidence-based interventions. Psychology, Health, and Medicine, 13, 450-460. doi:10.1080/13548500701687171

Brennan, D. (2014). Trafficking, scandal, and abuse of migrant workers in Argentina and the United States. Annals of the American Academy of Political and Social Science, 653, 107-123. doi:10.1177/0002716213519239

Brunovskis, A., \& Surtees, R. (2008). Agency or illness: The conceptualization of trafficking victims' choices and behaviors in the assistance system. Gender, Technology, and Development, 12, 53-76. doi:10.1177/097185240701200105

Brunovskis, A., Surtees, R. (2012a). Coming home: Challenges in family reintegration for trafficked women. Qualitative Social Work, 12, 454-472. doi:10.1177/1473325011435257

Brunovskis, A., \& Surtees, R. (2012b). Out of sight? Approaches and challenges in the identification of trafficked persons. Oslo, Norway: Allkopi AS.

Busch-Armendariz, N., Nsonwu, M. B., \& Heffron, L. C. (2014). A kaleidoscope: The role of the social work practitioner and the strength of social work theories and practice in meeting the complex needs of people trafficked and the professionals that work with them. International Social Work, 57, 7-18. doi:10.1177/ 0020872813505630

Chapkis, W. (2003). Trafficking, migration, and the law protecting innocents, punishing immigrants. Gender and Society, 17, 923-937. doi: $10.1177 / 0891243203257477$

Chin, K. L., \& Finckenauer, J. O. (2011). Chickenheads, agents, mommies, and jockeys: The social organization of transnational commercial sex. Crime, Law, and Social Change, 56, 463-484. doi:10.1007/s10611-011-9329-y

Cho, S. Y. (2013). Integrating equality: Globalization, women's rights, and human trafficking. International Studies Quarterly, 57, 683-697. doi:10.1111/isqu. 12056

Cho, S. Y., Dreher, A., \& Neumayer, E. (2013). Does legalized prostitution increase human trafficking? World Development, 41, 67-82. doi:10.1016/j.worlddev.2012.05.023

Chudakov, B., Ilan, K., Belmaker, R. H., \& Cwikel, J. (2002). The motivation and mental health of sex workers. Journal of Sex and Marital Therapy, 28, 305-315. doi:10.1080/00926230290001439
Collins, S. P., Goldenberg, S. M., Burke, N. J., Bojorquez-Chapela, I., Silverman, J. G., \& Strathdee, S. A. (2013). Situating HIV risk in the lives of formerly trafficked female sex workers on the Mexico-US border. AIDS Care, 25, 459-465. doi:10.1080/ 09540121.2012 .720361

Copley, L. (2014). Neutralizing their involvemen: Sex traffickers' discourse techniques. Feminist Criminology, 9, 45-58. doi:10.1177/ 1557085113501849

Crawford, M., \& Kaufman, M. R. (2008). Sex trafficking in Nepal: Survivor characteristics and long-term outcomes. Violence Against Women, 14, 905-916. doi:10.1177/1077801208320906

Decker, M. R., McCauley, H. L., Phuengsamran, D., Janyam, S., \& Silverman, J. G. (2011). Sex trafficking, sexual risk, sexually transmitted infection, and reproductive health among female sex workers in Thailand. Journal of Epidemiology and Community Health, 65, 334-339. doi:10.1136/jech.2009.096834

Deering, K. N., Chettiar, J., Chan, K., Taylor, M., Montaner, J. S., \& Shannon, K. (2012). Sex work and the public health impacts of the 2010 Olympic games. Sexually Transmitted Infections, 88, 301-303. doi:10.1136/sextrans-2011-050235

Dempsey, M. M. (2010). Sex trafficking and criminalization: In defense of feminist abolitionism. University of Pennsylvania Law Review, $158,1729-1778$.

Deshpande, N. A., \& Nour, N. M. (2013). Sex trafficking of women and girls. Reviews in Obstetrics and Gynecology, 6, e22.

Di Tommaso, M. L., Shima, I., Strøm, S., \& Bettio, F. (2009). As bad as it gets: Wellbeing deprivation of sexually exploited trafficked women. European Journal of Political Economy, 25, 143-162. doi:10.1016/j.ejpoleco.2008.11.002

Doezema, J. (1999). Loose women or lost women? The re-emergence of the myth of White slavery in contemporary discourses of trafficking in women. Gender Issues, 18, 23-50. doi:10.1007/ s12147-999-0021-9

Doezema, J. (2005). Now you see her, now you don't: Sex workers at the UN trafficking protocol negotiation. Social and Legal Studies, 14, 61-89. doi:10.1177/0964663905049526

Doezema, J. (2010). Sex slaves and discourse masters: The construction of trafficking. London, UK: Zed Books.

Fitzpatrick, J. (2002). Trafficking and a human rights violation: The complex intersection of legal frameworks for conceptualizing and combating trafficking. Michigan Journal of International Law, 24, 1143 .

Gallagher, A. (2001). Human rights and the new UN protocols on trafficking and migrant smuggling: A preliminary analysis. Human Rights Quarterly, 23, 975-1004. doi:10.1353/hrq.2001.0049

Gallagher, A. (2010). The international law of human trafficking. Cambridge, UK: Cambridge University Press.

Goodey, J. (2003). Migration, crime, and victimhood responses to sex trafficking in the EU. Punishment and Society, 5, 415-431. doi: $10.1177 / 14624745030054003$

Gould, C. (2010). Moral panic, human trafficking, and the 2010 soccer World Cup. Agenda, 24, 31-44. doi:10.1080/10130950.2010. 9676321

Haynes, D. F. (2004). Used, abused, arrested, and deported: Extending immigration benefits to protect the victims of trafficking and to secure the prosecution of traffickers. Human Rights Quarterly, 26, 221-272. doi:10.1353/hrq.2004.0021

Hom, K. A., \& Woods, S. J. (2013). Trauma and its aftermath for commercially sexually exploited women as told by front-line service providers. Issues in Mental Health Nursing, 34, 75-81. doi: 10.3109/01612840.2012.723300

Hoyle, C., Bosworth, M., \& Dempsey, M. (2011). Labelling the victims of sex trafficking: Exploring the borderland between rhetoric and reality. Social and Legal Studies, 20, 313-329. doi:10.1177/ 0964663911405394

Hua, J., \& Nigorizawa, H. (2010). U.S. sex trafficking, women's human rights, and the politics of representation. International Feminist Journal of Politics, 12, 401-423. doi:10.1080/14616742.2010.513109 
Hubbard, P., Matthews, R., \& Scoular, J. (2008). Regulating sex work in the EU: Prostitute women and the new spaces of exclusion. Gender, Place, and Culture, 15, 137-152. doi:10.1080/09663690701863232

Hughes, D. M. (2000). The "Natasha" trade: The transnational shadow market of trafficking in women. Journal of International Affairs-Columbia University, 53, 625-652.

Huisman, W., \& Kleemans, E. R. (2014). The challenges of fighting sex trafficking in the legalized prostitution market of the Netherlands. Crime, Law, and Social Change, 61, 1-14. doi:10.1007/s10611013-9512-4

International Labor Organization. (2012). Global estimate of forced labour 2012: Results and methodology. Geneva, Switzerland: International Labor Organization.

Jakobsson, N., \& Kotsadam, A. (2013). The law and economics of international sex slavery: Prostitution laws and trafficking for sexual exploitation. European Journal of Law and Economics, 35, 87-107. doi:10.1007/s10657-011-9232-0

Jayagupta, R. (2009). The Thai government's repatriation and reintegration programmes: Responding to trafficked female commercial sex workers from the Greater Mekong Subregion. International Migration, 47, 227-253. doi:10.1111/j.1468-2435.2008.00498.x

Jeffreys, S. (2009). Prostitution, trafficking, and feminism: An update on the debate. Women's Studies International Forum, 32, 316-320. doi:10.1016/j.wsif.2009.07.002

Jones, L., Engstrom, D., Hilliard, P., \& Sungakawan, D. (2011). Human trafficking between Thailand and Japan: Lessons in recruitment, transit, and control. International Journal of Social Welfare, 20, 203-211. doi:10.1111/j.1468-2397.2009.00669.x

Jordan, A. D. (2002). Human rights or wrongs? The struggle for a rights-based response to trafficking in human beings. Gender and Development, 10, 28-37. doi:10.1080/13552070215891

Kelly, L. (2003). The wrong debate: Reflections on why force is not the key issue with respect to trafficking in women for sexual exploitation. Feminist Review, 73, 139-144. doi:10.1057/palgrave. fr.9400086

Kenyon, S., \& Schanz, Y. (2014). Sex trafficking: Examining links to prostitution and the routine activity theory. International Journal of Criminology and Sociology, 3, 61-76. Retrieved from https:// www.ncjrs.gov/App/Publications/abstract.aspx?ID $=267352$

Kim, K., \& Hreshchyshyn, K. (2004). Human trafficking private right of action: Civil rights for trafficked persons in the United States. Hastings Women's Law Journal, 16, 1-36.

Konstantopoulos, W. M., Ahn, R., Alpert, E. J., Cafferty, E., McGahan, A., Williams, T. P.,... Burke, T. F. (2013). An international comparative public health analysis of sex trafficking of women and girls in eight cities: Achieving a more effective health sector response. Journal of Urban Health, 90, 1194-1204. doi:10.1007/s11524-013-9837-4

Leman, J., \& Janssens, S. (2013). Creative adaptive criminal entrepreneurs from Africa and human trafficking in Belgium: Case studies of traffickers from Nigeria and Morocco. International Journal of Criminology and Sociology, 2, 153-162. doi:10.6000/1929-4409.2013.02.15

Limoncelli, S. A. (2009). The trouble with trafficking: Conceptualizing women's sexual labor and economic human rights. Women's Studies International Forum, 32, 261-269. doi:10.1016/j.wsif.2009.05.002

Lindstrom, N. (2004). Regional sex trafficking in the Balkans: Transnational networks in an enlarged Europe. Problems of Post-Communism, 51, 45-52.

Lobasz, J. K. (2009). Beyond border security: Feminist approaches to human trafficking. Security Studies, 18, 319-344. doi:10.1080/ 09636410902900020

Lyneham, S., \& Larsen, J. J. (2013). Exploitation of Indonesian trafficked men, women, and children and implications for support. Trends and Issues in Crime and Criminal Justice, 450, 1-7.

Mai, N. (2013). Embodied cosmopolitanisms: The subjective mobility of migrants working in the global sex industry. Gender, Place, and Culture, 20, 107-124. doi:10.1080/0966369X.2011.649350
Mancuso, M. (2014). Not all madams have a central role: Analysis of a Nigerian sex trafficking network. Trends in Organized Crime, 17, 66-88. doi:10.1007/s12117-013-9199-z

Marcus, A., Horning, A., Curtis, R., Sanson, J., \& Thompson, E. (2014). Conflict and agency among sex workers and pimps: A closer look at domestic minor sex trafficking. Annals of the American Academy of Political and Social Science, 653, 225-246. doi:10.1177/0002716214521993

Marinova, N. K., \& James, P. (2012). The tragedy of human trafficking: Competing theories and European evidence. Foreign Policy Analysis, 8, 231-253. doi:10.1111/j.1743-8594.2011.00162.x

McIntyre, B. L. (2014). More than just rescue: Thinking beyond exploitation to creating assessment strategies for child survivors of commercial sexual exploitation. International Social Work, 57, 39-63. doi:10.1177/0020872813505629

Miriam, K. (2005). Stopping the traffic in women: Power, agency, and abolition in feminist debates over sex-trafficking. Journal of Social Philosophy, 36, 1-17. doi:10.1111/j.1467-9833.2005.00254.x

Molland, S. (2010). The value of bodies: Deception, helping, and profiteering in human trafficking along the Thai-Lao border. Asian Studies Review, 34, 211-229. doi:10.1080/10357823.2010.481042

Molland, S. (2011). The trafficking of scarce elite commodities: Social change and commodification of virginity along the Mekong. Asia Pacific Journal of Anthropology, 12, 129-145. doi:10.1080/ 14442213.2010 .546426

Muftić, L. R. (2013). Attitudes regarding criminal justice responses to sex trafficking among law enforcement officers in Bosnia and Herzegovina. Journal of Criminal Justice and Security, 2, $177-189$

Munro, V. E. (2006). Stopping traffic? A comparative study of responses to the trafficking in women for prostitution. British Journal of Criminology, 46, 318-333. doi:10.1093/bjc/azi070

Munro, V. E. (2008). Of rights and rhetoric: Discourses of degradation and exploitation in the context of sex trafficking. Journal of Law and Society, 35, 240-264. doi:10.1111/j.1467-6478.2008.00437.x

Nieuwenhuys, C., \& Pécoud, A. (2007). Human trafficking, information campaigns, and strategies of migration control. American Behavioral Scientist, 50, 1674-1695. doi:10.1177/00027642073 02474

O’Brien, E., Carpenter, B., \& Hayes, S. (2013). Sex trafficking and moral harm: Politicised understandings and depictions of the trafficked experience. Critical Criminology, 21, 401-415. doi:10.1007/ s10612-013-9183-6

O'Connor, M., \& Healy, G. (2006). The links between prostitution and sex trafficking: A briefing handbook. Dublin, Ireland: Coalition Against Trafficking in Women.

O'Connell Davidson, J. (2006). Will the real sex slave please stand up? Feminist Review, 83, 4-22. http://dx.doi.org/10.1057/palgrave.fr. 9400278

O'Connell Davidson, J. (2013). Troubling freedom: Migration, debt, and modern slavery. Migration Studies, 1, 176-195. doi:10.1093/ migration/mns002

Oram, S., Ostrovschi, N. V., Gorceag, V. I., Hotineanu, M. A., Gorceag, L., Trigub, C., \& Outshoorn, J. (2012). Policy change in prostitution in the Netherlands: From legalization to strict control. Sexuality Research and Social Policy, 9, 233-243. doi:10.1007/s13178-012-0088-z

Outshoorn, J. (2012). Policy change in prostitution in the Netherlands: From legalization to strict control. Sexuality Research and Social Policy, 9, 233-243. doi:10.1007/s13178-012-0088-z

Overs, C., \& Hawkins, K. (2011). Can rights stop the wrongs? Exploring the connections between framings of sex workers' rights and sexual and reproductive health. BMC International Health and Human Rights, 11, S6. doi:10.1186/1472-698X-11-S3-S6

Pajnik, M. (2013). Reconciling paradigms of prostitution through narration. Društvena Istraživanja, 22, 257-276. doi:10.5559/di.22.2.03

Pandey, S., Tewari, H. R., \& Bhowmick, P. K. (2013). Antecedents and reintegration of sex trafficked victims in India: A conceptual 
framework. International Journal of Criminal Justice Sciences, 8 , 47-62.

Pickering, S., \& Ham, J. (2014). Hot pants at the border: Sorting sex work from trafficking. British Journal of Criminology, 54, 2-19. doi: $10.1093 / \mathrm{bjc} /$ azt060

Piscitelli, A. (2012). Revisiting notions of sex trafficking and victims. Vibrant: Virtual Brazilian Anthropology, 9, 274-310. doi:10.1590/ S1809-43412012000100010

Raymond, J. G. (2002). The new UN trafficking protocol. Women's Studies International Forum, 25, 491-502. doi:10.1016/S02775395(02)00320-5

Reid, J. A. (2012). Exploratory review of route-specific, gendered, and age-graded dynamics of exploitation: Applying life course theory to victimization in sex trafficking in North America. Aggression and Violent Behavior, 17, 257-271. doi:10.1016/ j.avb.2012.02.005

Richards, K., \& Lyneham, S. (2014). Help-seeking strategies of victim/survivors of human trafficking involving partner migration. Trends and Issues in Crime and Criminal Justice, 468, 1-10.

Roe-Sepowitz, D., Gallagher, J., \& Hickle, K. (2014). Exploring sex trafficking and prostitution demand during the Super Bowl 2014. Washington, DC: Arizona State University School of Social Work, Office of Sex Trafficking Intervention Research.

Saunders, P. (2005). Traffic violations determining the meaning of violence in sexual trafficking versus sex work. Journal of Interpersonal Violence, 20, 343-360. doi:10.1177/0886260504272509

Scarpa, S. (2008). Trafficking in human beings: Modern slavery. Oxford, UK: Oxford University Press.

Schaeffer-Grabiel, F. (2010). Sex trafficking as the "new slave trade"? Sexualities, 13, 153-160. doi:10.1177/1363460709359234

Segrave, M., Milivojevic, S., \& Pickering, S. (2009). Sex trafficking. International context and response. New York, NY: Willan.

Shamir, H. (2012). A labor paradigm for human trafficking. UCLA Law Review, 60, 76-136.

Shelley, L. (2010). Human trafficking. A global perspective. Cambridge, UK: Cambridge University Press.

Siegel, D. (2012). Mobility of sex workers in European cities. European Journal on Criminal Policy and Research, 18, 255-268. doi:10.1007/s10610-011-9168-5

Silverman, J. G., Decker, M. R., Gupta, J., Maheshwari, A., Patel, V., Willis, B. M., \& Raj, A. (2007). Experiences of sex trafficking victims in Mumbai, India. International Journal of Gynecology and Obstetrics, 97, 221-226. doi:10.1016/j.ijgo.2006.12.003

Skeldon, R. (2000). Trafficking: A perspective from Asia. International Migration, 38, 7-30. doi:10.1111/1468-2435.00113

Soderlund, G. (2005). Running from the rescuers: New U.S. crusades against sex trafficking and the rhetoric of abolition. NWSA Journal, 17, 64-87. doi:10.2979/NWS.2005.17.3.64

Stoecker, S. (2000). The rise in human trafficking and the role of organized crime. Demokratizatsiya, 8, 129-144.

Surtees, R. (2004). Traditional and emergent sex work in urban Indonesia. Intersections: Gender, History, and Culture in the Asian Context, 10. Retrieved from http://intersections.anu.edu.au/ issue 10/surtees.html

Surtees, R. (2008a). Re/integration of trafficked persons: Handling "difficult" cases. Vienna, Austria: Nexus Institute.

Surtees, R. (2008b). Traffickers and trafficking in Southern and Eastern Europe: Considering the other side of human trafficking. European Journal of Criminology, 5, 39-68. doi:10.1177/ 1477370807084224

Surtees, R. (2010). Monitoring anti-trafficking re/integration programmes: A manual. Vienna, Austria: Nexus Institute.

Surtees, R. (2012). Re/integration of trafficked persons: Supporting economic empowerment. Vienna, Austria: Nexus Institute.

Todres, J. (2005). Importance of realizing other rights to prevent sex trafficking. Cardozo Journal of Law and Gender, 12, 885-907.

Todres, J. (2009). Law, otherness, and human trafficking. Santa Clara Law Review, 49, 605-672.
United Nations Office on Drugs and Crime. (2003a). Protocol against the smuggling of migrants by sand, sea, and air to the UN convention against transnational organized crime. Retrieved from http://www.unodc.org/unodc/treaties/CTOC/

United Nations Office on Drugs and Crime. (2003b). Protocol to prevent, suppress, and punish trafficking in persons to the UN convention against transnational organized crime. Retrieved from http://www.unodc.org/unodc/treaties/CTOC/

United Nations Office on Drugs and Crime. (2012). Global report on trafficking in persons. New York, NY: United Nations.

United Nations Office on Drugs and Crime. (2013). Issue paper: Abuse of a position of vulnerability and other "means" within the definition of trafficking in persons. New York, NY: United Nations.

U.S. Department of State. (2013). Trafficking in persons report. Washington, DC: U.S. Department of State.

Van Hook, M. P., Gjermeni, E., \& Haxhiymeri, E. (2006). Sexual trafficking of women: Tragic proportions and attempted solutions in Albania. International Social Work, 49, 29-40. doi:10.1177/ 0020872806057086

Väyrynen, R. (2003). Illegal immigration, human trafficking, and organized crime. Helsinki, Finland: World Institute for Development Economics.

Verhoeven, M., van Gestel, B., de Jong, D., \& Kleemans, E. (2013). Relationships between suspects and victims of sex trafficking: Exploitation of prostitutes and domestic violence parallels in Dutch trafficking cases. European Journal on Criminal Policy and Research, December, 1-16. doi:10.1007/s10610-013-9226-2

Vijeyarasa, R. (2010). The state, the family, and language of "social evils": Restigmatising victims of trafficking in Vietnam. Culture, Health, and Sexuality, 12, S89-S102. doi:10.1080/ 13691050903359257

Vijeyarasa, R. (2012). The Cinderella syndrome: Economic expectations, false hopes, and the exploitation of trafficked Ukrainian women. Women's Studies International Forum, 35, February, 53-62. doi:10.1016/j.wsif.2011.09.004

Vijeyarasa, R. (2013). Stigma, stereotypes, and Brazilian soap operas: Road-blocks to ending human trafficking in Vietnam, Ghana, and Ukraine. Gender, Place, and Culture, 20, 1015-1032. doi:10.1080/ 0966369X.2012.759905

Vindhya, U., \& Dev, V. S. (2011). Survivors of sex trafficking in Andhra Pradesh: Evidence and testimony. Indian Journal of Gender Studies, 18, 129-165. doi:10.1080/0966369X.2012.759905

Wagenaar, H., \& Altink, S. (2012). Prostitution as morality politics or why it is exceedingly difficult to design and sustain effective prostitution policy. Sexuality Research and Social Policy, 9, 279-292. doi:10.1007/s13178-012-0095-0

Weitzer, R. (2007). The social construction of sex trafficking: Ideology and institutionalization of a moral crusade. Politics and Society, 35, 447-475. doi:10.1177/0032329207304319

Wirth, K. E., Tchetgen, E. J. T., Silverman, J. G., \& Murray, M. B. (2013). How does sex trafficking increase the risk of HIV infection? An observational study from Southern India. American Journal of Epidemiology, 177, 232-241. doi:10.1093/aje/kws338

Wong, W. C., Holroyd, E., Chan, E. Y., Griffiths, S., \& Bingham, A. (2008). "One country, two systems": Sociopolitical implications for female migrant sex workers in Hong Kong. BMC International Health and Human Rights, 8, 13. doi:10.1186/1472-698X-8-13

Zhang, S. (2011). Sex trafficking in a border community: A field study of sex trafficking in Tijuana, Mexico. San Diego, CA: San Diego State University.

Zimmerman, C., Hossain, M., Yun, K., Gajdadziev, V., Guzun, N., Tchomarova, M.,...Watts, C. (2008). The health of trafficked women: A survey of women entering posttrafficking services in Europe. American Journal of Public Health, 98, 55-59. doi:10.2105/AJPH.2006.108357

Zimmerman, C., Kiss, L., Hossain, M., \& Watts, C. (2009). Trafficking in persons: A health concern? Ciência \& Saúde Coletiva, 14, 10291035. doi:10.1590/S1413-81232009000400010 